\title{
(O comunismo responde com a) Politização da arte
}

André Piazera Zacchi

UFSC

\begin{abstract}
Resumo
No presente ensaio proponho uma leitura da expressão "politização da arte" utilizada por Walter Benjamin na última linha de sua teoria estética, o ensaio $A$ obra de arte na era de sua reprodutibilidade técnica. Procuro conter a leitura dessa expressão na unidade do fragmento "Estética da guerra", o último do ensaio citado, para só então buscar aporte em outro ensaio, no qual Benjamin se preocupa com a poética: $O$ autor como produtor. "Politizar a arte" não passa por veicular nas obras uma tendência ideológica, mas dar atenção aos meios de sua produção, para que a obra de arte não seja mais um produto qualquer, apropriável pelo capitalismo, adulada com elogios de genialidade única do artista, mas um instrumento técnico ao alcance de todos.
\end{abstract}

Palavras-chave: Politização; Arte; Benjamin.

\begin{abstract}
In the present essay I propose a reading of the expression "politicizing art" used by Walter Benjamin in the last line of his aesthetic theory, the essay The work of art in the age of mechanical reproduction. I try to contain the reading of this expression in the unit of the fragment, the epilogue of the essay quoted, then proceed to another essay, in which Benjamin is concerned with poetics: The author as a producer. "Politicize art" is not an ideological tendency to convey in the works, but means to pay attention to the conditions of its production, so that the work of art is no longer any product, appropriated by capitalism, flattered with praise of the artist's unique genius, but a technical tool for everyone.
\end{abstract}

Keywords: Politicizing; Art; Benjamin. 
1. BENJAMIN, Walter. Obras Escolhidas, vol. 01 - Magia e técnica, arte e política, 1994 (1985), p. 196. (Em língua alemã, as linhas escritas por Benjamin: "So steht es um die Ästhetisierung der Politik, welche der Faschismus betreibt. Der Kommunismus antwortet ihm mit der Politisierung der Kunst”. Gesammelte Schriften - I, 1991, p. 469.)

2. Ibidem, p. 166.
É provável que nenhuma construção dialética tenha tido maior sucesso no século XX do que a famosa estetização da política pelo fascismo, e seu oposto, a politização da arte como resposta do comunismo. Para os interessados na relação entre arte e política esse parece ser o perfeito diagnóstico de um mundo "dominado" por uma estetização generalizada da política e, seu correlato, o papel da arte como gesto revolucionário. As palavras finais do ensaio de Walter Benjamin sobre a obra de arte parecem ter o mérito de uma exortação aos artistas, aos críticos e, enfim, a todos os revolucionários, para que politizem a arte e consigam, assim, uma redenção da política, opondo-se aos fascismos, da época, do presente, do porvir, enfim, da História.

"Eis a estetização da política, como a pratica o fascismo. O comunis-

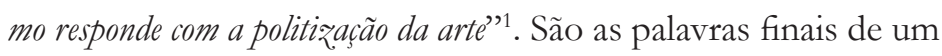
ensaio no qual Benjamin, diante de um fascismo crescente na Europa (1935), procura meios de que suas teses não sejam assimiladas, incorporadas e, com isso, percam a efetividade. Pensadas assim, as palavras soam mesmo como um grito de guerra, como uma resposta, como defesa de um fazer artístico revolucionário. Talvez seja o vazio aberto pela expressão "politização da arte" que permita tantas interpretações e usos, servindo de bandeira a movimentos políticos ou justificativa crítica diante de alguma "arte engajada". As leituras que um texto sempre exige, como condição de sobrevivência, precisam encarar esse vazio.

Gostaria então de propor um recuo, um passo atrás, sua releitura de forma menos abrangente, limitada mesmo. Em vez de estender a "politização da arte" a todos os domínios que encontrarmos, com a força retórica e apaixonante que uma arte política pode ter, defendo uma leitura afinada com o modo de escrever (e pensar) de Benjamin, com o ensaio do qual faz parte e, espero, com alcance reduzido, a expressão receba novas forças dessa contenção.

O ensaio sobre a obra de arte na era de sua reprodutibilidade técnica segue uma linha de pensamento paralela a uma linha de encadeamento textual. Isso se dá numa montagem bastante fragmentada de teses e argumentos que, a partir de uma visada histórica, lança hipóteses sobre o presente (europeu especificamente) e apontam conjuntamente para um diagnóstico e um uso. Ou seja, são conceitos sobre o fazer artístico, sobre a percepção estética, que "podem ser utilizados para a formulação de exigências revolucionárias na política artística"2. Assim se define o ensaio na introdução: um conjunto de teses e alguns prognósticos. Não é meu objetivo aqui resenhar cada conceito (reprodutibilidade técnica, autenticidade, valor de culto, valor de exposição, ritual, aura, valor de eternidade, cinema como arte, cinema e teste, intérprete de cinema, dadaísmo, pintor e cinegrafista, recepção tátil, recepção ótica, estética da guerra), mas 
evidenciar o fato de que cada conceito é uma pequena unidade a ser montada na escritura do ensaio. Cada uma das teses e seu conjunto no ensaio apontam para o fato de que há um desenvolvimento técnico que modifica o conceito de obra de arte, desenvolvimento correlato ao crescimento das massas proletarizadas. Outro fato notório é que há um represamento das forças revolucionárias dessa arte técnica pois seu uso ainda é fascista, ainda individualizante e anestesiante ${ }^{3}$.

Benjamin montou várias versões para o ensaio. A mais utilizada no Brasil ainda é a publicada em 1985 pela Editora Brasiliense no volume Obras escolbidas I-Magia e técnica, arte e política traduzida por Sérgio Paulo Rouanet. Antes dela, em 1969, tivemos uma tradução da "segunda versão" por José Lino Grünnewald, incluída no volume $A$ ideia do cinema ${ }^{5}$. Recentemente a editora Autêntica publica a "quinta versão", desta vez traduzida e anotada por João Barrento. Concedi preferência a esta última, em virtude de ser fruto das releituras do próprio Benjamin e pela coesão na argumentação principal (deixando muitas digressões para as notas) e pelas produtivas observações do tradutor/ pesquisador. Outro detalhe importante é que, nesta versão, os capítulos não recebem títulos, mas, exceto o prefácio e o posfácio, cada unidade recebe apenas numerais romanos.

Sabe-se que Benjamin era um colecionador de brinquedos infantis, mas também, e especialmente, de citações. Quando encontrava um trecho que gostava, copiava-o num cartão e guardava para montagem futura. Quase um método de trabalho. Mas não eram apenas citações. Suas imagens de pensamento ${ }^{6}$ vertiam-se em pequenos textos que também aumentavam a coleção. Não era, entretanto, uma facilitação ao trabalho posterior, mas o próprio trabalho principal, que consistia em retirar fragmentos de seu contexto e rearranjá-los de modo que um ilumine o outro, como explica Hannah Arendt:

When he was working on his study of German tragedy, he boasted of a collection of "over 600 quotations very systematically and clearly arranged" (Briefe I, 339); like the later notebooks, this collection was not an accumulation of excerpts intended to facilitate the writing of the study but constituted the main work, with the writing as something secondary. The main work consisted in tearing fragments out of their context and arranging them afresh in such a way that they illustrated one another and were able to prove their raison d'etre in a free-floating state, as it were. It definitely was a sort of surrealistic montage. ${ }^{7}$

Seus ensaios são montagens de fragmentos. Na maioria dos textos o método é evidente: Parque Central, Sobre alguns temas em Baudelaire, Rua de Mão única, Imagens do pensamento, Infância Berlinense: 1900, Teses sobre o conceito de história, O narrador. Como
3. Susan Buck-Mors trabalha as teses em torno do potencial anestesiante de uma estética fascista em: "Estética e anestética - o "ensaio sobre a obra de arte" de Walter Benjamin reconsiderado". Travessia n. 33, ago-dez 1996, p. 12.

4. BENJAMIN, Walter. Obras Escolhidas, vol. 01 - Magia e técnica, arte e politica. 1994 (1985).

5. Idem. "A obra de arte na época de suas técnicas de reprodução", 1969.

6. Idem. Imagens do pensamento/ Sobre o Haxixe e outras drogas, 2013.

7. ARENDT, Hannah. "Introduction", 1969, p. 47. 
8. BENJAMIN, Walter. Passagens de Walter Benjamin, 2006.

9. Idem. Obras Escolbidas, vol. 01 - Magia e técnica, arte e política, 1994, p. 175.

10. Ibidem, p. 129.

11. Ibidem, p. 107.

12. Ibidem, p. 101. expoente, grande arquivo de citações, fragmentos e aforismos, que um projeto editorial reuniu em Passagens ${ }^{8}$. Em outros casos, a montagem se esconde numa aparente continuidade, ausência de separadores, mas com uma série de digressões que interrompem a leitura e a fragmentam. E fragmentos que se repetem em outras montagens. Muitas vezes lendo ensaios de Benjamin nos deparamos com um parágrafo que, com pequenas alterações, já havíamos lido em outro lugar. Muitas vezes o mesmo conceito, ou o mesmo fragmento, compondo textos distintos.

Um dos exemplos dessa repetição é quando Benjamin defende a necessidade de legenda para as imagens, especialmente à fotografia. Isso permitiria ler a imagem em dois tempos, e fazer dela montagem, carregá-la de história. A defesa aparece pelo menos em três textos famosos, que cito abaixo. Primeiramente no ensaio sobre a obra de arte, quando o texto diz:

Nas revistas, as legendas explicativas se tornam pela primeira vez obrigatórias. É evidente que esses textos têm um caráter completamente distinto dos títulos de um quadro. As instruções que um observador recebe dos jornais ilustrados através das legendas se tornarão, em seguida, ainda mais precisas e imperiosas no cinema, em que a compreensão de cada imagem é condicionada pela sequencia de todas as imagens anteriores. ${ }^{9}$

Mas algo do mesmo conceito se repete em $O$ autor como produtor: "Temos de exigir dos fotógrafos a capacidade de colocar em suas imagens legendas explicativas que as liberem da moda e lhes confiram um valor de uso revolucionário"10. E, no prototexto sobre a obra de arte, Pequena história da fotografia:

Aqui deve intervir a legenda, introduzida pela fotografia para favorecer a literalização de todas as relações da vida e sem a qual qualquer construção fotográfica corre o risco de parecer vaga e aproximativa. (...) Mas um fotógrafo que não sabe ler suas imagens não é pior que um analfabeto? Não se tornará a legenda a parte mais essencial da fotografia ${ }^{11}$

A pequena história da fotografia também traz o conceito de aura, quase idêntico, palavra por palavra, àquele apresentado no ensaio da obra de arte. "Em suma, o que é aura? É uma figura singular, composta de elementos espaciais e temporais... possuir o objeto... retirar o objeto de seu invólucro... captar o semelhante... fenômeno único..."12. E há tantas outras recorrências. Sobre alguns temas em Baudelaire repete, em alguns trechos, integralmente, Paris do Segundo Império. O expediente não é sem importância, pois coloca em cena a recorrência de um bloco de texto em outra montagem, concedendo a ele uma nova possibilidade de leitura, ou seja, novas legendas. Poderíamos conformar 
assim um método benjaminiano, fazendo da escritura uma constante montagem. Escrever conceitos em algumas linhas e reutilizar (algumas vezes as próprias linhas) em diversas articulações de sentido.

Em Rua de Mão Única, composição absolutamente fragmentária, Benjamin enaltece o método genial, onde o gênio não é o autor, mas o próprio labor que demanda o fragmento, que se torna a oficina de um trabalho árduo, incessante, de montagem e de recorrência:

Para os grandes, as obras acabadas têm menos peso do que aqueles fragmentos ao fio dos quais o trabalho atravessa a suas vidas. Só os mais fracos, os mais distraídos, sentem uma alegria incomparável ao terminar alguma coisa, sentindo-se, com isso, restituídos à sua vida. Para o gênio, toda e qualquer cesura, os pesados golpes do destino, e também o sono sereno, são parte do trabalho diligente da sua oficina. Ele traça o campo de ação desta no fragmento. "Gênio é trabalho diligente". 13

O ensaio sobre a obra de arte não foge a esse método. Cada capítulo, cada unidade reunida sob um subtítulo ou um número, guarda certa unidade, condensa um conceito, que será montado com os demais. É possível dizer que é a forma de seu ensaio, a forma que, pelo apelo à montagem, se torna aberta, em formação. Ou, como se costuma atribuir a Benjamin, um método constelacional: cada unidade é uma das estrelas da constelação que, juntas, formam o desenho para um ponto de vista. Por um lado, uma imagem ajuda a ler a outra, trabalhando mutuamente como "legenda", mas por outro, cada conceito é também uma unidade para futura montagem, cada tese oscila, monadologicamente, entre o todo e o fragmento. Assim, a leitura que gostaria de propor da expressão "politização da arte" passa por esse exercício de contenção, de pensar a expressão dentro de suas unidades que the conferem o sentido mais imediato: o próprio fragmento e o ensaio no qual o fragmento está inserido.

O posfácio do ensaio está nomeado, na primeira versão, de "Estética da guerra"14. Nele, Benjamin traça um paralelo entre a proletarização do homem e as massas contemporâneas, organizadas pelo fascismo de modo a não abolirem as relações de produção e propriedade. A solução fascista é permitir às massas a expressão de sua natureza (serem filmadas, aparecerem no cinema), mas não a expressão de seus direitos. O cinema é a reprodução em massa, mas é também a reprodução da massa, onde ela vê seu próprio rosto, num aparelho próprio à apreensão de seus movimentos. "As massas têm o direito de exigir a mudança das relações de propriedade; o fascismo permite que elas se exprimam, conservando, ao mesmo tempo, essas
13. BENJAMIN, Walter. Obras Escolhidas, vol. 01 - Rua de mão única, 1994, p. 16.

14. Ibidem, p. 194. No texto alemão, em sua primeira versão, os subtítulos estão no índice, mas no texto há apenas numerais romanos que separam os fragmentos. Este é o fragmento [XIX]. Na segunda versão, esse capítulo, então décimo-sexto, entretanto, recebeu o nome de "Nachtwort" (epílogo ou posfácio). 
15. Ibidem, p. 195.

16. RANCIÈRE, Jacques. A partilha do sensivel, 2005.

17. Idem. "A Estética como política”, 2010.

18. Ibidem, p. 20.

19. Ibidem, p. 21. relações. Ele desemboca, consequentemente, na estetização da vida política"15. Rancière nos diria, comentando e contrapondo Benjamin, que toda vida política é estética, pois na polis, a partilha do sensível já ocorre entre as visibilidades, os direitos de se fazer ver, de ser visto, de falar, enfim, de participar das instâncias visíveis dessa polis, de sua estética. A vida na polis, a vida política, é desde sempre estética ${ }^{16}$. Essas hipóteses, presentes em $A$ partilha do sensivel, de 1996, são ampliadas pelo texto $A$ Estética como politica, de $2002^{17}$. Rancière parte da premissa de que rompemos com a utopia estética, que já não acreditamos numa radicalidade da arte que possa modificar as condições de existência coletiva. Após uma breve resenha das atitudes contemporâneas diante dessa descrença, reafirma seu conceito de regime "estético" das artes, no qual a arte teria a capacidade de recortar e instituir o tempo e o espaço. A política seria, então,

a configuração de um espaço específico, a partilha de uma esfera particular de experiência, de objetos colocados como comuns e originários de uma decisão comum, de sujeitos reconhecidos como capazes de designar esses objetos e argumentar a respeito deles. ${ }^{18}$

A política consiste em reconfigurar a partilha do sensível que define o comum de uma comunidade, em nela introduzir novos sujeitos e objetos, em tornar visível o que não era visto e fazer ouvir como falantes os que eram percebidos como animais barulhentos. Esse trabalho de criação de dissenso constitui uma estética da política que nada tem a ver com as formas de encenação do poder e de mobilização das massas designadas por Benjamin como "estetização da política". 19

Haveria, assim, uma estética da política que não seria a estetização denunciada por Benjamin, haveria uma política que é sempre estética pelo regime de visibilidades, recortes de espaço e tempo que propõe. Nesse regime estético não há oposição entre as formas da arte e as formas da comunidade, tampouco há arte autônoma e arte inserida no comum, politizada. Deve ser possível, discursivamente, separar a arte do ordinário, para que se a identifique como tal, mas ao mesmo tempo des-autonomizá-la, pois ela só conhece sua potência quando partilha o comum.

Portanto, não há a partir daí como concluir por uma captação fatal da arte pela "estética". Mais uma vez, não há arte sem uma forma específica de visibilidade e de discurso que a identifique como tal. Nada de arte sem uma certa partilha do sensível que a vincule a uma certa forma de política. A estética é essa partilha. A tensão entre as duas políticas ameaça o regime estético da arte. Mas é também o que o faz funcionar. Destacar essas lógicas opostas e o ponto 
extremo onde ambas se suprimem não nos leva, portanto, de modo algum, a declarar o fim da estética como outros declaram o fim da política, da história ou das utopias. Mas pode nos ajudar a entender as coerções paradoxais que recaem sobre o projeto, aparentemente tão simples, de uma arte "crítica", situando na forma da obra a explicação ou a confrontação daquilo que o mundo é com aquilo que ele poderia ser. ${ }^{20}$

Walter Benjamin parece saber que toda política é estética, mas denuncia uma estetização anestésica por um fascismo que, com o uso da fotografia e do cinema, assegura a continuidade das relações de propriedade diante da emergência das massas. Os gregos tinham os escravos, homens subjugados que não participavam da política. O fascismo - que pode ser um método de lidar com as massas como se não houvesse diferença interna (um feixe) - encontrou um jeito delas reivindicarem (e conseguirem) sua visibilidade, apagando, no afã estétizante, seu direito a transformar as relações de produção. Mas a técnica está aí, pronta para colocar as massas diante de uma nova ontologia da arte, e os fascismos precisam encontrar um modo de dar vazão à técnica sem modificar as relações de produção. O lugar desse dispêndio, diz Benjamin, é a guerra. A guerra fornece um objetivo aos movimentos de massa, anestesiando seu potencial revolucionário. Do ponto de vista técnico, a guerra mobiliza os recursos desenvolvidos pelo homem, não para sua fruição, nem para uma mudança das relações de trabalho e produção (tecnologia a serviço da vida), mas para encontrar uma válvula de escape, para que o progresso técnico não ameace a propriedade privada.

Benjamin então, nessa altura do capítulo, cita um trecho do manifesto futurista de Marinetti, que espantosamente afirma a beleza estética da guerra e de seus instrumentos técnicos, contrapondo o uso da técnica de modo natural, a serviço do homem, e seu uso antinatural, pela guerra. Uma espécie de revolta da técnica que cobra em material humano, na guerra, a falta de naturalidade de seu uso. Mas o fascismo, que facilmente poderia ter o futurismo como programa estético, aposta na guerra como satisfação técnica dos progressos tecnológicos e como satisfação artística dessa percepção modificada pela técnica (a tal percepção na era da reprodutibilidade). Assim, arremata Benjamin: "Sua auto-alienação [do homem] atingiu o ponto que lhe permite viver sua própria destruição como um prazer estético de primeira ordem. Eis a estetização da política, como a pratica o fascismo. O comunismo responde com a politização da arte" ${ }^{\text {"21 }}$.

Eis o final do parágrafo, que vem a ser o final do ensaio, assumindo nesta posição um grande poder retórico. Mas se reduzimos seu alcance e pensamos que a frase encerra apenas o
20. Ibidem, p. 36.

21. BENJAMIN, Walter. Obras Escolbidas, vol. 01 - Magia e técnica, arte e política, 1994, p. 196. 
22. JAY, Martin. Campos de Fuerza: entre la historia intelectual y la critica cultural, 2003.

23. Ibidem, p. 146.

24. Ibidem, p. 146. Tradução minha do espanhol.

25. BENJAMIN, Walter. Estética e sociologia da arte, 2017, p. 23.

26. JAY, Martin. Campos de Fuerza: entre la historia intelectualy la crítica cultural, 2003, p. 148. capítulo, fascismo e comunismo jogam como forças contrárias, em uma dialética sem síntese, na qual cada polo é apresentado em seu modo de encarar o desafio das massas. O capítulo foi inteiramente dedicado à estetização da política pelo fascismo, culminando na guerra e na sua tão absurda (e tão factível) apropriação estética. Há uma antítese ao fascismo, apresentada nesse ensaio como comunismo, que não estetiza a política, nem com fins comunitários, mas responde com a politização da arte. E, notemos, não se trata da politização da estética, como poderia sugerir uma leitura espelhada. A politização da estética seria, por exemplo, a emancipação do espectador de cinema, do leitor de imagens, fazendo com que ele questione criticamente as visibilidades que se lhe oferecem. Nessa hipótese o objeto artístico, ou técnico, ainda faria parte de um sistema cooptado pelo modo de produção burguês, no qual o artista entrega um produto e o discurso da arte lhe confere um sentido. A politização que Walter Benjamin propõe, como resposta do comunismo, é da arte. Este ponto deve se fazer notar: não é uma formula quiasmática, espelhada, de ações inversas. Politizar a arte não é a práxis oposta àquela praticada pelo fascismo, de estetizar a política. É uma ação-resposta, um contra-ataque do comunismo (da política que defende as massas e seus direitos) à estetização da política pelo fascismo, nos exemplos fornecidos por Benjamin.

Além de Rancière, Martin Jay também tem se dedicado ao tema, especialmente em seu "A ideologia estética" como ideologia o que significa estetizar a política? ${ }^{22}$ faz um inventário minucioso das hipóteses que vinculam estética e política, denunciando sua abordagem moralizante, na medida em que consideram, por diversos motivos, tal vínculo pernicioso. A partir daí, Jay faz a ressalva de que é preciso encontrar, antes de tudo, a noção de estética que, ao ser estendida para o âmbito político, provoca esse juízo negativo ${ }^{23}$. Levanta algumas hipóteses. A primeira delas procede da tradição de l'art pour l'art de diferenciar uma esfera chamada "arte" daquelas outras buscas humanas, cognitivas, religiosas, éticas, econômicas ou de qualquer índole ${ }^{24}$. Uma política estetizada nesse sentido excluiria deliberadamente tais outros aspectos, fundando seu juízo de valor unicamente no mérito estético, desinteressando-se pelo que seria o cerne da política: a vida humana. É nesse sentido que a denúncia de Benjamin diz, sobre a humanidade, que "a alienação de si própria atingiu o grau que lhe permite viver a sua própria aniquilação como um prazer estético de primeira ordem"25. Outra possibilidade levantada por Jay seria a estetização como a redução de um público ativo à condição de "massas" passivas, transformadas em material maleável, moldado para o triunfo da vontade do artista/político ${ }^{26}$. Como terceira hipótese, a estetização seria a vitória do espetáculo sobre a esfera pública, reduzindo a política 
a este. Nessas três hipóteses associa-se a estética à ilusão, ao simulacro, à irracionalidade, ao mito, à sedução dos sentidos, à imposição da vontade e à indiferença humana às questões éticas, cognitivas, religiosas ${ }^{27}$. Porém há uma quarta hipótese que se relaciona com aquilo que críticos modernos como Paul de Man e Eagleton denunciaram como "ideologia estética".

La estética en cuestión no se entiende como lo opuesto de la razón, sino, antes bien, como su complemento; no como la expresión de una voluntad irracional sino como la versión sensual de una noción de racionalidad superior, más general; no como el espectáculo silencioso de las imágenes, sino como la realización de un absoluto literario. En suma, es una estética concebida como la culminación de la filosofía idealista o tal vez incluso de la metafísica occidental en su conjunto y no como su negación abstracta. Lo que se toma, pues, como punto de partida de la política estetizada es la cultura burguesa en su expresión más elevada antes que en su momento de aparente decadencia. ${ }^{28}$

Todas essas hipóteses referidas por Martin Jay, inclusive a última, têm em comum o fato de tomarem a estetização da política como algo negativo, mau, que a afasta de suas preocupações fundamentais relacionadas ao homem e seus direitos. Mas Jay dá um passo no sentido de encontrar pensadores que lêem de maneira positiva o vínculo entre estética e política. Cita dois deles: Lyotard e Hanna Arendt. Eles fariam notar, então, que nem toda relação entre os dois termos conduz a um resultado tenebroso. Nesse gesto de leitura, Jay evidencia que a crítica à ideologia estética burguesa (e à sua inerente política), tão frequente no século XX, pode tornar-se também ideológica, quando tende para a homogeneização e totalização, usando da mesma violência que costuma atribuir à estetização da vida.

Walter Benjamin não escreveu essas teses apenas como resposta ao fascismo que crescia na Europa. Muitas de suas teses afrontavam ou endossavam pensamentos da época, de seus mestres e/ou colegas, correspondentes, teóricos da arte, da política, da cultura. Um desses interlocutores, com quem o ensaio estabelece uma relação de proximidade e refutação, foi Carl Schmitt. Em Romantismo Politico, publicado em 1919, Schmitt defendia a tese de que o Romantismo provocava uma estetização e uma economicização da vida e seguia, em pleno século XX, mostrando seus efeitos políticos. Uma vida banalizada, tornada um conjunto de fatos econômicos sob o domínio da técnica. Esse movimento só poderia ser revertido com o retorno à política pura, separada da estética, ou seja, quando as gestões políticas pararem de se vender como obras de arte. Posteriormente, em uma conferência intitulada Na época das neutralizações e despolitizaçoes, de 1929, Schmitt segue defendendo que a política
27. Ibidem, p. 149.

28. Ibidem, p. 150. 
29. CANTISANI, Alejandro; ILIEFF, Ricardo Laleff. "Política y economía en el romanticismo alemán. Un contrapunto en torno a las hermenéuticas de Carl Schmitt y Walter Benjamin". In: Anacronismo y Irrupción, Vol. $2 \mathrm{~N}^{\circ} 3$ Noviembre 2012 a Mayo 2013 - pp. 87-112.

30. Ibidem, p. 150.

31. Ibidem, p. 109 e ss. seu tempo, herdeira do Romantismo, ainda articula forças estéticas que conduzem a uma neutralização de si mesma, negando a política pura, criando-lhe um véu econômico e estetizante. As aproximações entre as teses de Schmitt e as de Benjamin, bem como sua diferença fundamental, que se joga no campo da práxis (ou seja, da crença de Schmitt rechaçada por Benjamin de uma pureza teórica da política e da arte) e um rigoroso estudo dos alcances dessa comparação podem ser encontradas no ensaio de Alejandro Cantisani e Ricardo Laleff Ilieff ${ }^{29}$. Segundo a posição de Schmitt, esclarecem, o esteticismo romântico forneceria as bases para o liberalismo desestruturar o político, colocando a vida sob uma perspectiva econômica e tecnicamente estandardizada.

Benjamin, assim como Schmitt, encontra na tendência individualizante do Romantismo uma "faceta burguesa", mas diverge em sua leitura geral (prefere fragmentá-lo), apostando no potencial filosófico e político do proto-romantismo. Também vê a íntima ligação entre economicização e estetização como herança do Romantismo, mas não aceita conceber a política em uma sociedade moderna sem essa relação. Antes de defender um essencialismo do político que se oponha aos efeitos da estetização, propõe uma maneira de ler historicamente essa práxis humana chamada "política" de forma a construir uma política tática e estrategicamente efetiva ${ }^{30}$. Defendem Cantisani e Ilieff que há uma lógica constitutiva compartilhada pela práxis política e pela obra de arte pós-aurática, e que não basta separar seus campos de atuação teoricamente para que a estetização da política não se produza. A autonomia, tanto da obra de arte quanto da política é uma pretensão teórica, já que estão sempre atravessadas, ou melhor, estão constituídas, por práxis sociais. Assim como não há uma política pura, a arte não se reduz à estética. Ambas ultrapassam, na vida, seus pretensos campos teóricos. Mas há uma diferença: "La diferencia sustancial radica en que no sería posible pensar la política sin politización, mientras que sí sería posible pensar un arte sin estetización". Partindo da aparente semelhança entre as teorias de Schmitt e Benjamin, os autores puderam lançar profundas hipóteses para aquilo que Benjamin chamou de estetização da política e politização da arte. Suas conclusões, até certo ponto apresentadas aqui, fornecem aportes substanciais para sustentar que a politização da arte, tese que este ensaio pretende subscrever, não é uma resposta espelhada e contrária à estetização da política, antes uma aposta nas massas e seu potencial de práticas artísticas compatíveis com suas políticas (comunistas) ${ }^{31}$.

Voltando à interpretação topográfica, buscada no posfácio, a politização da arte promoveria um curto-circuito nas relações de produção fascistas, privatizantes, mantenedoras da 
propriedade. Ou seja, o comunismo simplesmente responde produzindo a arte de maneira diferente daquela produzida no sistema fascista. A estetização da política é a produção técnica de gozos estéticos (o cinema, a guerra) nos quais as massas se vêem e se aniquilam sem a mise-en-scène de seu direito principal: mudar as relações de produção. A resposta comunista é a arte, por isso politizada desde a sua produção, ou seja, uma técnica que traz na sua fatura o signo dessa revolução, visa desmanchar a relação proprietário/proletário. Essa arte, para ser verdadeiramente revolucionária, precisa estar comprometida com a transformação dos meios de produção.

Alguns anos antes de escrever o ensaio sobre a obra de arte, Walter Benjamin realiza uma conferência no Instituto para o Estudo do Fascismo, intitulada $O$ autor como produtor ${ }^{32}$. Nela, elabora uma teoria da poética, ou seja, do fazer artístico. Inicia perguntando se um autor (literário) é livre para escrever o que quiser. A opinião do público que o escuta, supõe Benjamin, é a de que o escritor burguês, ao destinar suas obras à diversão, não está livre, trabalha a serviço de certos interesses de classe, embora não o admita. O escritor progressista, ao contrário, sabe que tem escolha, e escolhe o proletariado na luta de classes, orienta sua escrita nesse sentido, pondo fim na sua autonomia. "Costuma-se dizer que ele obedece a uma tendência" 33. Assim, o artista politicamente engajado seguiria uma tendência, geralmente progressista, enquanto o artista burguês seria alguém alienado que, sem saber, defenderia uma outra tendência, reacionária. Além disso, o debate atual (para a época, mas que permanece atual) é saber como conjugar uma tendência política com uma qualidade artística. Benjamin se apressa em afirmar que esse debate em torno das tendências é estéril, que não permite conhecer o fascismo. A tendência política correta se mostra apenas, única e exclusivamente, numa correta tendência artística, que é sua qualidade. Com isso se desfaz a aparente dualidade entre um artista (e uma arte) que sustente um discurso de defesa disso ou daquilo. O importante numa obra, e no fazer artístico, se quisermos pensar na sua relação com a política, é a maneira pela qual participa das relações de produção. E a maneira pela qual conjuga esforços para sua transformação. O artista/intelectual/ produtor paradigmático nessa inserção da obra nessas relações seria Bertold Brecht. Não estava separado da classe social, para a qual aportaria inteligência, pensamento ${ }^{34}$. Buscava não abastecer um sistema de produção, mesmo que produzindo material revolucionário, mas modificá-lo. Ou seja, não apenas produzir, mas produzir meios de produção revolucionária ${ }^{35}$.

Essa exigência é hoje mais imperiosa que nunca. Um escritor que não ensina outros escritores não ensina ninguém.
32. BENJAMIN, Walter. Obras

Escolbidas, vol. 01 - Magia e técnica, arte e politica, 1994, p. 120 e ss.

\section{Ibidem, p. 121.}

34. Benjamin critica o Ativismo, como reinado da inteligência, ou reinado dos intelectuais, já que cria uma categoria que "pensaria melhor" que os líderes de classe, mas ao mesmo tempo estaria afastada já que investe no pensamento individual. Isso culmina numa postura de detenção à luta: "Vemos aqui onde conduz a concepção do 'intelectual' como tipo definido por suas opiniões, convicções e disposições, e não por sua posição no processo produtivo. Como diz Döblin, ele deve encontrar seu lugar ao lado do proletariado. Que lugar é esse? O lugar de um protetor, de um mecenas ideológico. Um lugar impossível”. Ibidem, p. 127.

35. $\mathrm{O}$ autor também critica a "Nova Objetividade" que abastece um aparelho produtivo sem modificá-lo, ainda que os materiais fornecidos tenham a aparência revolucionária. Há uma espécie de estetização da vida proletária, da miséria, transformando tudo em moda. Ibidem, p. 128. 
36. Ibidem, p. 132.

37. Ibidem, p. 134.

38. Ibidem, p. 136.

39. RANCIÈRE, Jacques. As distâncias do cinema, 2012, p.126.
O caráter modelar da produção é, portanto, decisivo: em primeiro lugar ela deve orientar outros produtores em sua produção e, em segundo lugar, precisa colocar à disposição deles um aparelho mais perfeito. Esse aparelho é tanto melhor quanto mais conduz consumidores à esfera da produção, ou seja, quanto maior for sua capacidade de transformar em colaboradores os leitores ou espectadores. Já possuímos um modelo desse gênero, do qual só posso falar aqui rapidamente. É o teatro épico de Brecht. ${ }^{36}$

Um modelo dessa produção artística revolucionária, um modelo de politização da arte como possível resposta à estetização da política é o modelo brechtiano. Com a interrupção da ação, segundo Benjamin, Brecht propõe nada menos que a montagem da arte com a vida, suspendendo a ilusão por parte do público, fazendo-o assombrar-se com as condições reais que se representam diante dele e exercendo uma função organizadora. "Seu objetivo não é tanto alimentar o público com sentimentos, ainda que de revolta, quanto aliená-lo sistematicamente, pelo pensamento, das situações em que vive" ${ }^{37}$. Tudo se resume, para Benjamin, na capacidade de autorreflexão do artista:

Consegue promover a socialização dos meios de produção intelectual? Vislumbra caminhos para organizar os trabalhadores no próprio processo produtivo? Tem propostas para a refuncionalização do romance, do drama, da poesia? Quanto mais completamente o intelectual orientar sua atividade em função dessas tarefas, mais correta será a tendência, e mais elevada, necessariamente, será a qualidade técnica de seu trabalho. Por outro lado, quanto mais exatamente conhecer sua posição no processo produtivo, menos se sentirá tentado a apresentar-se como intelectual puro (Geistiger). A inteligência que fala em nome do fascismo deve desaparecer. A inteligência que o enfrenta, confiante em suas próprias forças miraculosas, há de desaparecer. Porque a luta revolucionária não se trava entre capitalismo e a inteligência, mas entre capitalismo e proletariado. ${ }^{38}$

A arte politizada é aquela realizada em outro modo de produção e que tem como horizonte mudar todo o sistema produtivo. Não é apenas um produto, mas uma poética que exige da recepção (estética) uma participação, uma arte que demanda montagem, que interrompe o fluxo da ação (no paradigma brechtiano) e organiza o pensamento, combatendo a ilusão de uma hipnose anestésica.

Rancière propõe que atualmente, no cinema, se adote um modelo pós-brechtiano ${ }^{39}$. Seria uma utopia pensar que o cinema fosse capaz de suprimir os afastamentos entre arte, vida e política. As expectativas investidas nessa arte crítica caíram inexoravelmente em contradições. 
O modo como são vistas as ambiguidades do cinema já é marcado pela duplicidade do que se espera dele: que suscite consciência, pela clareza de um desvelamento, e energia, pela apresentação de uma estranheza; e que revele a um só tempo toda a ambiguidade do mundo e como lidar com essa ambiguidade. Projeta-se no cinema a obscuridade da relação que se pressupõe entre a clareza da visão e as energias da ação. Se o cinema pode esclarecer a ação, talvez seja questionando a evidência dessa relação. ${ }^{40}$

Questionando a evidência da relação entre arte e política, o cinema deveria ser pós-brechtiano, ciente das aporias da emancipação e das ações de justiça. O que o cinema pode é colocar corpos em cena, encadear ações, apresentar o que é próprio da imagem, sua distinção e a força da identidade visível. "O cinema não apresenta um mundo que cabe a outros transformar (...) A eficácia política das formas da arte deve ser construída pela política em seus próprios cenários" ${ }^{\prime 4}$. Ou seja, a politização da arte para Rancière é uma atividade crítica que consiste em fazer os dois discursos se atravessarem, fazer a arte jogar o jogo da política, usar de suas formas, de suas narrativas, de suas potências para alcançar efetividades, que lhe serão sempre agregadas e que não estariam em sua forma. Fazer a arte separar-se discursivamente do ordinário, e paradoxalmente, montar-se com a vida, onde reencontra sua práxis política. Poderíamos chamar esse trânsito de estética.

É fundamental pensarmos esses afastamentos, essas distâncias entre arte e política. Pode haver muitas maneiras de politizar a arte, mas a proposta de Benjamin tem o mérito de não ser apropriada pelo fascismo, porque envolve a própria destruição das relações tradicionais de produção. Realmente o cinema não teve essa capacidade, apesar de suas características técnicas, encontrou um meio de renovar o culto, dessa vez ao próprio capital. O que, talvez, ainda caiba aos cineastas, é encontrar outras formas de produção, politizando o cinema, fazendo dele uma condição de sensibilidade nessa era de reprodutibilidades ${ }^{42}$. É preciso fazer do cineasta um produtor, não um intelectual deslocado das massas, veiculador de tendências ainda que progressistas. Praticar, nos filmes, exercícios de corte e repetição que despertem as imagens para as montagens da história e despertem as audiências do sono das imagens, ou seja, ainda um esforço brechtiano, para que, na interrupção e sua demanda de montagem, sejamos todos cineastas.
40. Ibidem, p. 23.

41. Ibidem, p. 24.

42. Em uma coletânea de ensaios publicada no Chile em 2012 e intitulada: ¿Qué es un aparato estético? - Benjamin, Lyotard, Rancière, Jean-Louis Déotte retoma a questão pelo enfoque da técnica. Critica especialmente Rancière por querer reduzir os regimes de identificação da arte (para chegar no já citado regime estético) à retórica, e com isso não precisar pensar seu substrato técnico. A leitura de Déotte, ao contrário, quer colocar a técnica no centro da questão, desenvolvendo um conceito próprio de aparelho. Especialmente ao tratar do texto sobre a obra de arte, destaca a reprodutibilidade como condição de possibilidade da produção artística. Produção e reprodução, assim, se identificam. A produção artística não consiste, segundo Déotte/ Benjamin, em formalizar (miseen-forme) uma matéria informe, mas sim em deformar, dissolver, fazer ruína para que se libere uma aparição. São esses aparelhos que condicionam a percepção e, por conseguinte, condicionam a estética. A fotografia e o cinema fazem época dando lugar a uma sensibilidade comum. São aparelhos estéticos, como também o são a perspectiva, o museu, a cura psicanalítica; ou seja, condicionam a sensibilidade como um molde. Mas a técnica (a reprodutibilidade trazida pelo cinema e pela fotografia) ainda não está politicamente inervada como prótese da percepção humana, o culto ainda se renova. Politizar a arte, nesse sentido, seria se apropriar (fazer as massas se apropriarem, inervarem) do aparelho, concebendo, pelo jogo, pela distração, pela citada deformação, novos objetos da arte, transindividuais, que nascem da própria técnica. 


\section{Referências}

CANTISANI, Alejandro; ILIEFF, Ricardo Laleff. "Política y economía en el romanticismo alemán. Un contrapunto en torno a las hermenéuticas de Carl Schmitt y Walter Benjamin". Anacronismo y Irrupción. Vol. 2 N 3, p. 87-112, noviembre 2012 a mayo 2013.

BENJAMIN, Walter. Estética e sociologia da arte. Edição e tradução João Barrento. Belo Horizonte: Autêntica Editora, 2017.

_. Gesammelte Schriften - I. Frankfurt: Suhrkamp Verlag, 1991.

Illuminations. Translated by Harry Zohn. Edited and with an introduction by Hannah Arendt. New York: Schocken Books, 1969.

. Imagens do pensamento/Sobre o Haxixe e outras drogas.

Edição e tradução de João Barrento. Belo Horizonte: Autêntica Editora, 2013.

. Obras Escolbidas, vol. 01 - Magia e técnica, arte e política.

Tradução Sérgio Paulo Rouanet. São Paulo: Brasiliense, 1994.

Obras Escolhidas, vol. 02 - Rua de mão única. Tradução

Sérgio Paulo Rouanet. São Paulo, Brasiliense, 1995.

Passagens de Walter Benjamin. TIEDEMANN, Rolf;

BOLLE, Willi; MATOS, Olgária Chaim Feres (Org.). Tradução Irene Aron e Cleonice P. B. Mourão. Belo Horizonte: UFMG/ Imprensa Oficial de São Paulo, 2006.

BUCK-MORSS, Susan. "Estética e anestética - o "ensaio sobre a obra de arte" de Walter Benjamin reconsiderado". Tradução Rafael Lopes Azize. Travessia. n. 33, p. 11-41, ago-dez 1996.

DÉOTTE, Jean-Louis. ¿Qué es un aparato estético? - Benjamin, Lyotard, Rancière. Tradução Francisca Salas Aguayo. Santiago de Chile: Metales Pesados, 2012.

GRÜNNEWALD, José Lino (org.). A idéia do cinema. Seleção, tradução e prefácio de José Lino Grünnewald. Rio de Janeiro: Editora Civilização Brasileira, 1969.

JAY, Martin. Campos de Fuerza: entre la bistoria intelectual y la crítica cultural. Traducción Alcira Bixio. Buenos Aires: Paidós, 2003. 
RANCIÈRE, Jacques. "A Estética como política”. Tradução Augustin de Tugny. Revista Devires. v. 7, n. 2, p. 14-36, Belo Horizonte, Jul-dez 2010.

- A partilha do sensivel: estética e política. Tradução de Mônica Costa Neto. São Paulo: EXO Experimental org., Ed. 34, 2005.

- As distâncias do cinema. Tradução Estela dos Santos

Abreu. Rio de Janeiro: Contraponto, 2012.

Submissão: 10/05/2017

Aceite: 20/07/2017 